УДК: 531.383

\author{
V.V. Chikovani
}

National aviation university, Kyiv

\title{
FIBER-OPTIC GYRO VERSUS CORIOLIS VIBRATORY ONE
}

Fiber optic gyro (FOG) and metallic resonator Coriolis vibratory gyro (CVG) main accuracy parameters are compared in this paper. Manufacturers of the analyzed gyros are from Russia (FOG) and Ukraine (CVG). Methodics to measure and to calculate scale factor temperature instability and nonlinearity as well as bias components such as quantum noise, random walk and drift using Allan variance analysis are described. Scale factors temperature instability and nonlinearity graphs of both gyros are given and compared. Bias components calculation at stable temperature are also given and compared. Two CVGs: KVG25, KVG43 and one FOG: VG951D take part in comparative analysis.

Key words: Coriolis vibratory gyro, fiber optic gyro, Allan variance, scale factor, nonlinearity, temperature instability.

\section{Introduction}

Recently metallic cylindrical resonator Coriolis vibratory gyro (CVG) has been developed and tested in Ukraine. This CVG have shown so promising accuracy parameters that it can take in nearby future leading position in the world by cost/quality ratio.

Metallic resonator manufacturing cost is much less than that made of quarts material and fiber optic coil with polarization maintaining fiber for middle and high accuracy fiber optic gyro (FOG). Metallic resonator CVG can be manufactured by any enterprise with standard modern mechanical equipment. Its capability to mass production on the basis of computerized mechanical processing centers will reduce the manufacturing cost even more.

At the same time FOG has no such high produceability like CVG. CVG sensing element consists of only three parts [1], which assembly is simple and takes short time. CVG reliability more than 10 times exceeds that of FOG [2].

It should be noted in addition that CVG can operate in rate and rate-integrating modes and these modes can be realized in one CVG with possibility to switch from one mode to another in dependence on character of angle rate change to reduce measurement errors [5] that makes it more adaptable to different area of applications. FOG can operate in either rate or rate-integrating mode without possibility to combine them in one FOG.

The aim of this work is to compare basic parameter of metallic resonator CVG developed and produced by Ukrainian company with the same parameters of the middle grade Russian produced FOG. Comparison is conducted on the basis of shortly described in the next section methodic to measure and calculate scale factor temperature instability and nonlinearity. The two gyros bias components such as quantum noise, random walk and drift are compared using Allan variance analysis recommended by international IEEE gyro standards on CVG [3] and FOG [4] which are also shortly described in the next section.

\section{Methodics to calculate gyro parameters}

There is a problem of gyro drift components statistical parameters determination to characterize gyro accuracy. Allan variance method recommended by IEEE standards is comparatively simple one and allows one to estimate noises intensity of different nature. The essence of this method is to sequentially increase averaging time of a gyro drift measurement and to draw a graph of root square of averaged drift variance (i.e. standard deviation) versus averaging time. One can in detail be familiarized with Allan variance calculation methodic in Annex C of IEEE FOG standard [4]. Here, common view of Allan variance curve is shown and different slope intervals on it are showed. These different slopes characterize such bias components as quantum noise, angle random walk, correlated Markov-like noise, bias instability and others.

Typical curve of Allan standard deviation is presented in fig.1 [4]. It could present or absent any of indicated error components in this graph. So, for different gyros this curve may look unequal.

Each specific error component from fig. 1 can be written down as follows:

$$
\begin{gathered}
\sigma_{Q}(T)=Q \frac{\sqrt{2}}{n T} ; \sigma_{N}(T)=N \frac{1}{n T} ; \\
\sigma_{B}(T)=\frac{2 \ln 2}{\pi} B \approx 0.664 B ; \\
\sigma_{K}(T)=K \sqrt{\frac{n T}{2}} ; \sigma_{R}(T)=R \frac{n T}{\sqrt{2}} ;
\end{gathered}
$$




$$
\sigma_{M}(T)=M \sqrt{\frac{n T}{2}} ; \ldots
$$

here $Q$ is a random drift due to quantum noise measured in degrees; $N$ is random drift due to angle random walk measured in $\mathrm{deg} / \mathrm{h}^{1 / 2} ; B$ is random drift due to bias instability measured in $\mathrm{deg} / \mathrm{h} ; K$ is random drift due to rate random walk measured in $\mathrm{deg} / \mathrm{h}^{3 / 2} ; R$ is random drift due to rate ramp measured in $\mathrm{deg} / \mathrm{h}^{2} ; M$ is random drift due to exponentially correlated Markov noise measured in $\mathrm{deg} / \mathrm{h}^{3 / 2}$.

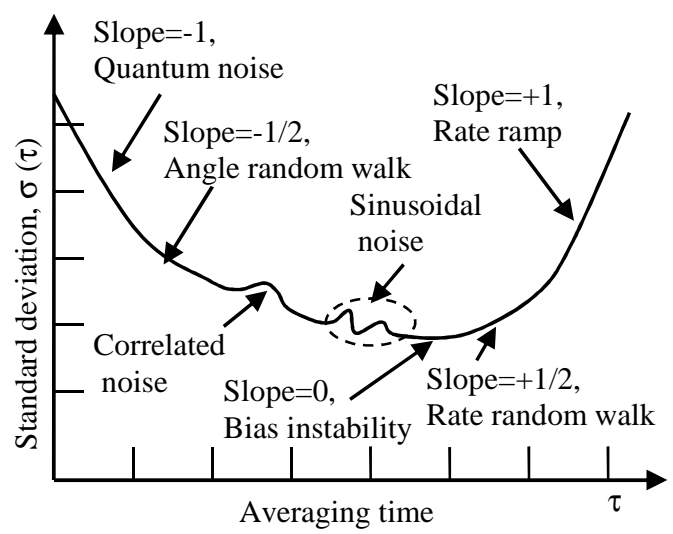

Fig.1. Typical Allan standard deviation versus averaging time

As can be seen from (1) Q value in deg is determined as an ordinate of intersection point of tangential line with slope $=-1(\tan \alpha=-1)$ to $\sigma_{\Omega}(\tau)$ curve (drawn in log-log scale, and calculated in $\operatorname{deg} / \mathrm{h}$ ) and vertical line originating from the point $\tau=\sqrt{ } 3 \mathrm{~h}$. If $\tau<\sqrt{3} \mathrm{~h}$, then $\tau=\sqrt{3}$ sec can be taken and in this case $\mathrm{Q}$ is measured in arc sec.

$N$ is determined in $\mathrm{deg} / \mathrm{h}^{1 / 2}$ as an intersection point ordinate of tangential line with slope $=-0.5(\tan \alpha=-0.5)$ to $\sigma_{\Omega}(\tau)$ curve and vertical line originating from the point $\tau=1 \mathrm{~h}$. If $\tau<1 \mathrm{~h}$, then $\tau=1 \mathrm{sec}$ can be taken and in this case $N$ is measured in deg $/ \mathrm{h} / \sqrt{ } \mathrm{Hz}, \operatorname{deg} / \sqrt{ } \mathrm{h}^{1 / 2}=60 \mathrm{deg} / \mathrm{h} / \sqrt{ } \mathrm{Hz}$.

$B$ is determined in $\mathrm{deg} / \mathrm{h}$ as an ordinate of minimum $\sigma_{\Omega}(\tau)$ (or its flat part) divided by constant $2 \ln 2 / \pi \approx 0.664$.

$K$ is determined in $\mathrm{deg} / \mathrm{h}^{3 / 2}$ as an intersection point ordinate of tangential line with slope 0.5 to $\sigma_{\Omega}(T)$ curve and vertical line originating from the point $T=\sqrt{ } 3 h$. If $\mathrm{T}<\sqrt{ } 3 h$, then $T=\sqrt{ } 3 \mathrm{sec}$ can be taken and in this case $K$ is measured in $\mathrm{deg} / \mathrm{h} / \widehat{ }_{\mathrm{sec}}, 60 \mathrm{deg} / \mathrm{h}^{3 / 2}=\mathrm{deg} / \mathrm{h} / \widehat{ }_{\mathrm{sec}}$.

$R$ is determined in $\mathrm{deg} / \mathrm{h}^{2}$ as an intersection point ordinate of tangential line with slope +1 to $\sigma_{\Omega}(\tau)$ curve and vertical line originating from the point $\tau=\sqrt{ } 2 h$. If $\tau<\sqrt{ } 2 h$, then $\tau=\sqrt{ } 2$ sec can be taken and in this case $R$ is measured in $\mathrm{deg} / \mathrm{h} / \mathrm{sec}, \mathrm{deg} / \mathrm{h}^{2}=3600 \mathrm{deg} / \mathrm{h} / \mathrm{sec}$.

Standard process of gyro scale factor measurement over temperature range is to stabilize gyro at each of prescribed temperatures $T_{i}, i=1 \ldots n$, from the operation temperature range and to rotate it counterclockwise and clockwise at the prescribed constant angle rate $\pm \Omega_{\mathrm{r}}$ during 3-5 min., for instance, as depicted in fig. 2 .

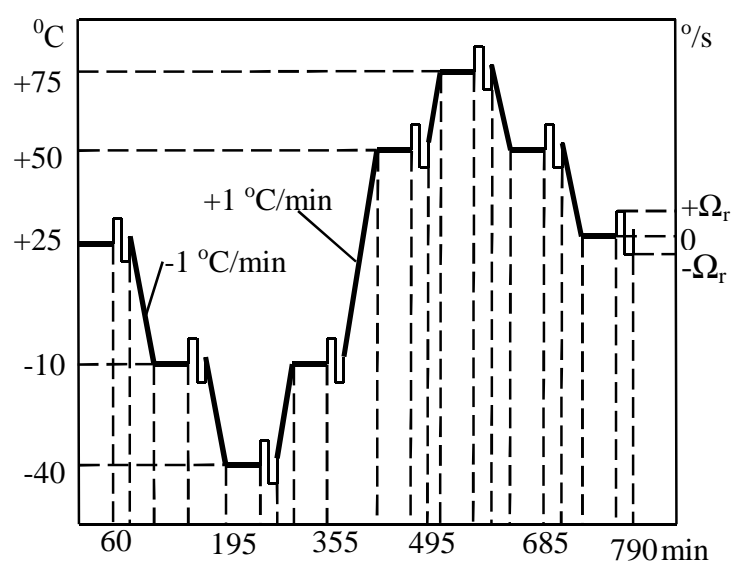

Fig.2. Temperature profile under scale factor measurement

Gyro scale factor can be calculated using expression:

$$
S F\left(T_{i}\right)=\frac{V^{+}\left(T_{i}\right)-V^{-}\left(T_{i}\right)}{2 * \Omega_{i}},
$$

where $\operatorname{SF}\left(T_{i}\right)$ is gyro scale factor at the temperature $T_{i}$, $V^{+}\left(T_{i}\right)$ is average value of gyro output signal when rotating counterclockwise at the temperature $T_{i}, V\left(T_{i}\right)$ is average value of gyro output signal when rotating clockwise at the temperature $T_{i}$.

After measurement of gyro scale factor at each of prescribed temperatures, scale factor temperature instability $S F_{T, i n s t}$ can be calculated using the following expression:

$$
S F_{T, \text { inst }}=\frac{\sigma_{S F}}{\overline{S F}} 100 \% \text {, }
$$

where $\sigma_{S F}$ is root mean square vale of scale factor over temperature range, $\overline{S F}$ is scale factor mean value over temperature range.

Standard process of gyro scale factor nonlinearity measurement is to rotate gyro around its sensing axis counterclockwise and clockwise with different prescribed angle rates at stable temperature as depicted in fig.3.

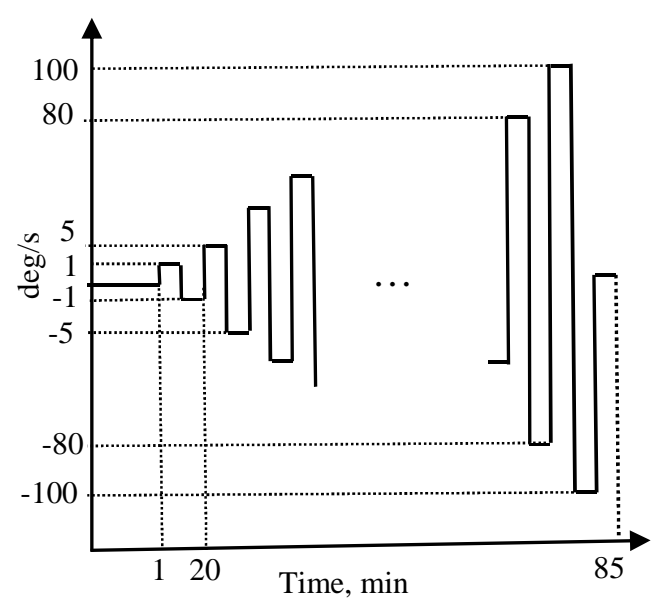

Fig.3. Angle rate profile under scale factor nonlinearity measurement 
After scale factor calculation at each angle rate using expression:

$$
S F\left(\Omega_{i}\right)=\frac{V^{+}\left(\Omega_{i}\right)-V^{-}\left(\Omega_{i}\right)}{2 * \Omega_{i}},
$$

where $\operatorname{SF}\left(\Omega_{i}\right)$ is gyro scale factor at $\Omega i$ angle rate, $V^{+}\left(\Omega_{i}\right)$ is average value of gyro output signal when rotating counterclockwise with $\Omega_{i}$ angle rate, $V\left(\Omega_{i}\right)$ is average value of gyro output signal when rotating clockwise with $\Omega_{i}$ angle rate, scale factor nonlinearity can be determined by the expression:

$$
S F_{\text {nonlin }}=\frac{\sigma_{S F}}{\overline{S F}} 100 \%,
$$

where $\sigma_{S F}$ is root mean square vale of scale factor over measurement range, $\overline{S F}$ is scale factor mean value over measurement range.

\section{The compared gyros}

Fig.4 shows gyros to be compared. They are CVGs KVG25 (a) dimensions: height $5.8 \mathrm{~cm}$, length $7.2 \mathrm{~cm}$; width $6.2 \mathrm{~cm}$, weight 400 gr., CVG KVG43 (the same view but bigger in size, so it is not shown) dimensions: height $5.8 \mathrm{~cm}$, length $9.0 \mathrm{~cm}$; width $8.2 \mathrm{~cm}$, weight $600 \mathrm{gr}$, both produced by JSC “Kyiv's plant Automatica named after G.I. Petrovsky" (Ukraine), FOG VG951D (b) produced by Fizoptica company (Russia) dimensions: height 3.1 $\mathrm{cm}$, diameter $15 \mathrm{~cm}$, weight $800 \mathrm{gr}$.

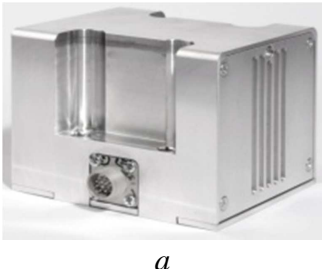

Fig.4. CVG KVG25 (a) and FOG VG951D

\section{Bias components comparison}

Allan standard deviations $\sigma_{\Omega}(T)$ computed for each of three gyros at stable temperature are shown in fig. 5, 6, 7. Two coefficients $Q=0.72$ arc sec and $N=0.003$ $\mathrm{deg} / \sqrt{\mathrm{h}}$ for CVG25 and $Q=0.55$ arc sec and $N=0.0005$ $\mathrm{deg} / \mathrm{Vh}$ for CVG43 which characterize noise components are significantly less than those of FOG VG951D which are equal to $\mathrm{Q}=18$ arc sec and $\mathrm{N}=0.25 \mathrm{deg} / \sqrt{\mathrm{h}}$.

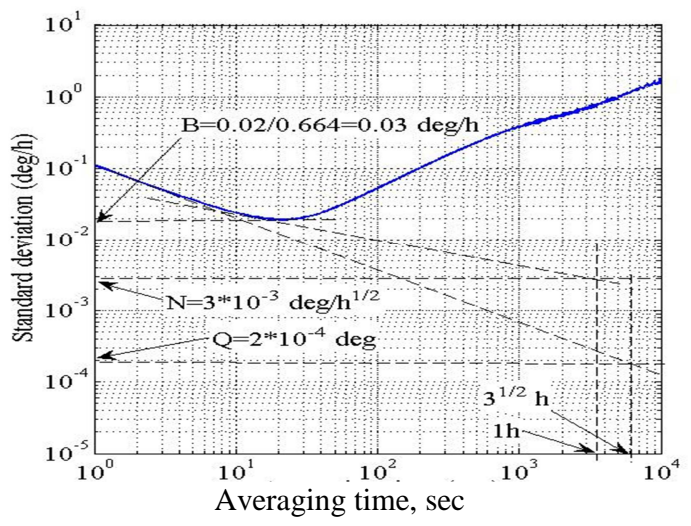

Fig.5. Q, N and B coefficients for CVG KVG25

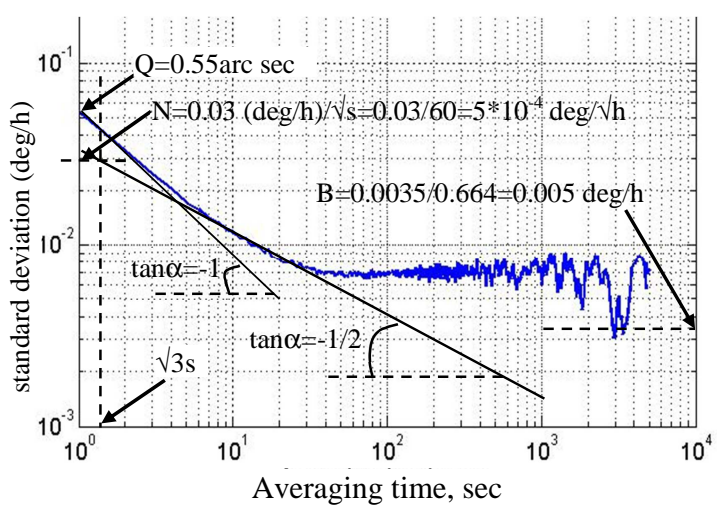

Fig. 6. $Q, N$ and B coefficient for CVG KVG43

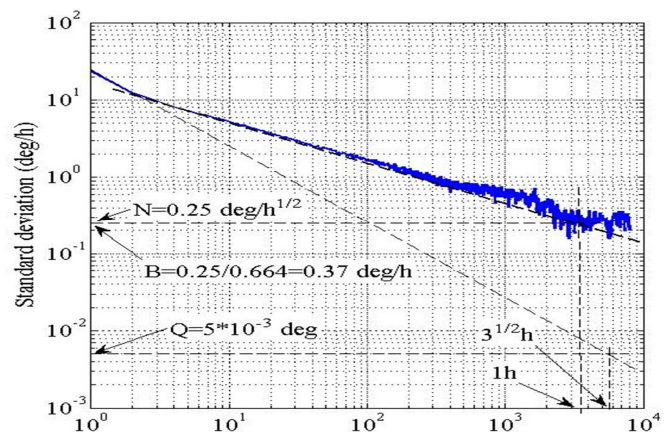

Averaging time, sec

Fig.7. Q, N and B coefficients for FOG VG951D

Bias instability determined by coefficient $\mathrm{B}$ is also significantly less for CVG25 and CVG43 which are 0.03 $\mathrm{deg} / \mathrm{h}$ and $0.005 \mathrm{deg} / \mathrm{h}$, respectively, than that of for FOG VG951D with value of $0.25 \mathrm{deg} / \mathrm{h}$.

In addition, as can be seen from fig.7, FOG Allan curve has a convex at the region of $1000 \mathrm{~s}$. In accordance with typical curve of fig. 1 it means that there is exponentially correlated Markov noise in the FOG VG951D drift characterized by $M$ coefficient. Fig. 8 shows how can be determined $M$ coefficient (root mean square (RMS) value of the noise amplitude) and its correlation time $T_{c}$.

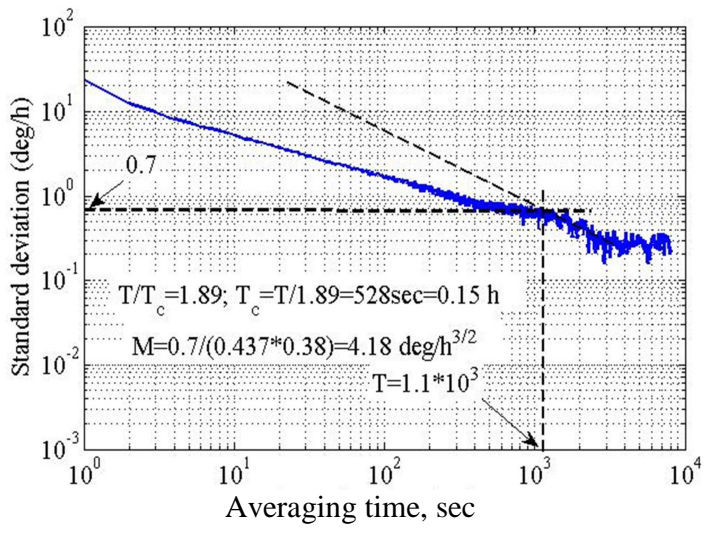

Fig.8. M coefficient and correlation time for VG951D

Correlation time $T_{c}$ is determined by the ratio $T / T_{c}=1.89$ [4], where $T$ is averaging time at which 
maximum convex part of the curve is reached. This maximum is reached at $T \approx 1100 \mathrm{~s}$, so $T_{c} \approx 1100 / 1.89=528$ s. Maximum of this convex part is $0.7 \mathrm{deg} / \mathrm{h}$, so for $M$ coefficient we obtain [4, Annex C]:

$$
0.437 M \sqrt{ } T_{c}=0.7 \rightarrow M=0.7 /(0.437 * \sqrt{ } 0.15)=4.18 \mathrm{deg} / \mathrm{h}^{3 / 2}
$$

Thus, this is exponentially correlated Markov noise in the output of FOG VG951D with the following parameters: RMS value of amplitude is $4.18 \mathrm{deg} / \mathrm{h}^{3 / 2}$ and correlation time is $T_{c} \approx 528 \mathrm{~s}$, that is correlation function of this noise is $K(\tau)=4.18 \mathrm{e}^{\tau / 528}$, where $\tau$ is measured in seconds.

\section{Scale factor accuracy comparison}

Fig. 9 and 10 show scale factors nonlinearity for CVG KVG25 and FOG VG951D in the angle rate range $\pm 200 \mathrm{deg} / \mathrm{s}$ and $\pm 70 \mathrm{deg} / \mathrm{s}$, respectively. As can be seen from these figures RMS values of nonlinearity are $0.025 \%$ for KVG25 and $3 \%$ for VG951D. FOG technical passport declares that rate range in $\pm 80 \mathrm{deg} / \mathrm{s}$, but scale factor nonlinearity in this range is much worse.

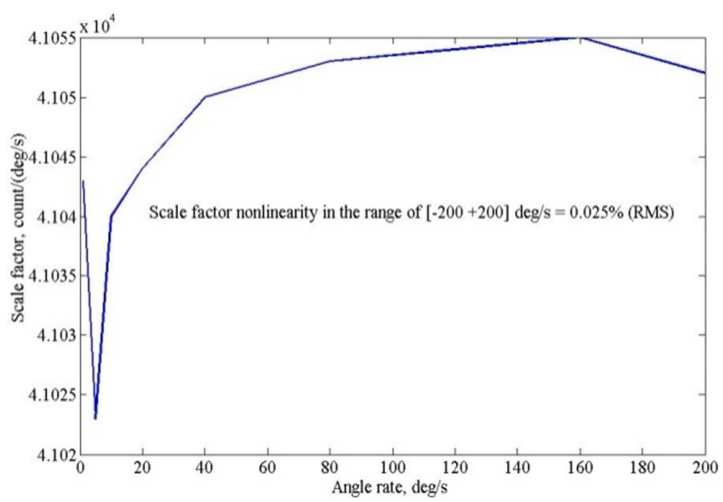

Fig.9. CVG KVG25 scale factor nonlinearity

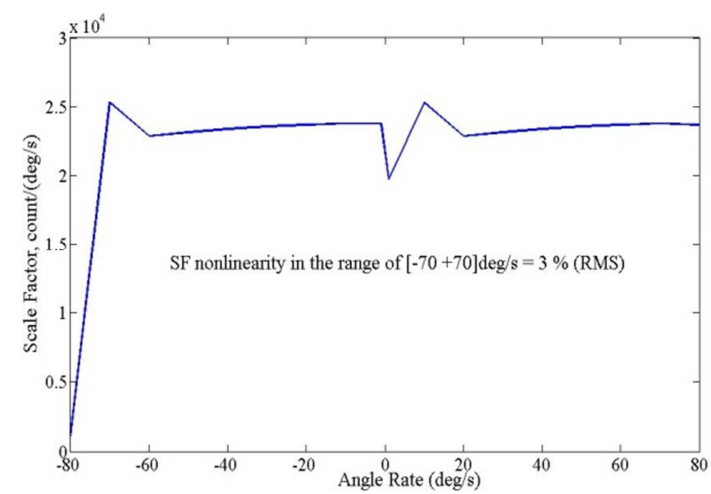

Fig.10. FOG VG951D scale factor nonlinearity

Fig. 11 and 12 show scale factors temperature instability in the temperature ranges $[-40+75]^{0} \mathrm{C}$ for

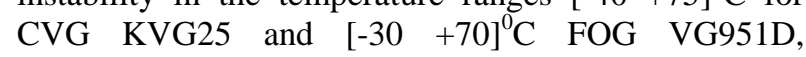
respectively. As can be seen from these figures RMS values of scale factors instability are $0.25 \%$ for KVG25 and $3 \%$ for VG951D.

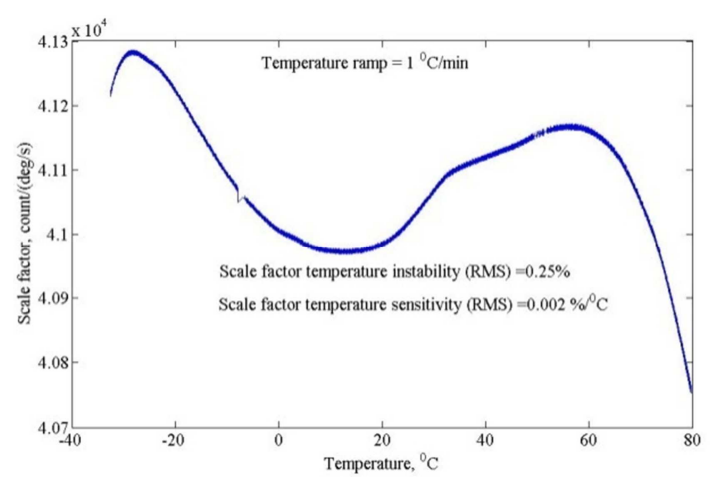

Fig.11. CVG KVG25 scale factor instability

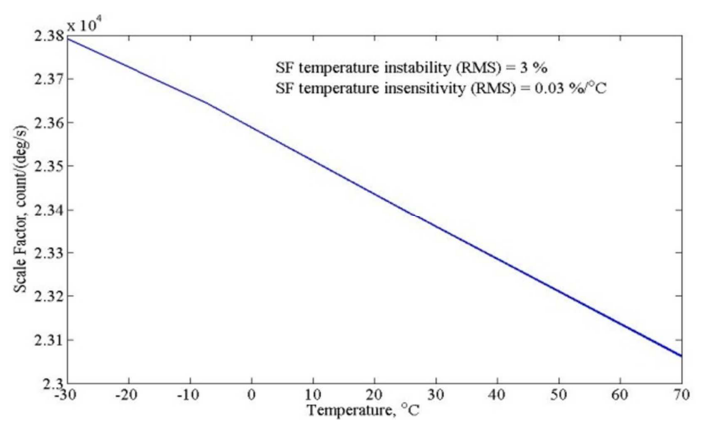

Fig.12. FOG VG951D scale factor instability

Calculations of scale factors temperature sensitivity for both gyros give the following results: for $\mathrm{KVG} 25-$ $0.002 \% /^{\circ} \mathrm{C}$ and for VG951D $-0.03 \% /{ }^{\circ} \mathrm{C}$. The difference is more than an order of magnitude.

\section{Conclusion}

CVG KVG 25 produced by Ukrainian company has significant advantages on major drift parameters over one of the high accurate FOG VG951D produced by Russian company Fizoptica. CVGs KVG25 and KVG43 have much less noise and an order of magnitude less bias drift, than that of FOG VG951D.

KVG25 and KVG43 using metallic resonator cost lower, than FOG and have mean time between failure of about ten times more [2], than that of FOG.

\section{References}

1. V.V. Chikovani «High reliable vibratory gyro with digital output».- IX Intern. Conf. «Gyrotechnology, navigation, motion control and aerospace technology development», Kyiv, NTUU «KPI», 17 -18 April 2013, v.1, p. 324-331 (in Russian).

2. V.V. Chikovani, S.P. Maliarov «Methodic and calculation mean time between failure by the results of Coriolis vibratory gyro test». - Viyskoho-tekhnichny zbirnik, Lviv: Sagaidachny Akademia sukhoputnykh viysk \#2 (5), 2011, p.119-124 (in Russian).

3. IEEE Standard Specification Format Guide and Test Procedure for Coriolis Vibratory Gyros.- IEEE Aerospace and Electronic Systems Society, IEEE std.1431 TM 2004.

4. IEEE Standard Specification Format Guide and Test Procedure for Single-Axis Interferometric Fiber Optic Gyros.IEEE Aerospace and Electronic Systems Society, IEEE std.1997 (R2003).

5. D.D. Lynch, A. Matthews "Dual Mode Hemispherical Resonator Gyro Operating Characteristics". - 3-rd S. Petersburg Int. Conf. on Integrated Navigation Systems, part 1, pp. 37-44, 1996.

Рецензент: д.т.н., проф. Л.С. Житецкий, НАУ, Киев. 
Волоконно-оптичний гіроскоп в порівнянні з коріолісовим вібраційним гіроскопом

В.В. Чіковані

У иій роботі проводиться порівняння точностних параметрів волоконно-оптичного гіроскопа (ВОГ) $i$ коріолісового вібрачійного гіроскопа (КВГ) з металевим резонатором. Виробниками гіроскопів, цуо аналізуються, є Росія (ВОГ) і Украйна (КВГ). Описуються методики вимірювання і розрахунок температурної нестабільності $i$ нелінійності масштабних коефічієнтів, а також таких компонент зміщення нуля, як шум квантування, випадкове блукання і дрейф, використовуючи аналіз варіації Аллана. Приводяться графіки температурної нестабільності $i$ нелінійності масштабних коефіцієнтів обох гіроскопів $i$ проводиться їх порівняння. Розраховуються також компоненти зміщення нуля при стабільної температурі і проводиться їх порівняння. У порівняльному аналізі беруть участь два КВГ: КВГ25, КВГ43 і один ВОГ ВГ941Д.

Ключеві слова: коріолісовий вібрачійний гіроскоп, волоконно-оптичний гіроскоп, варіацї Аллана, маситабний коефіиієнт, нелінійність, температурна нестабільність.

\section{Волоконно-оптический гироскоп в сравнении с кориолисовым вибрационным гироскопом}

\section{В.В. Чиковани}

В этой работе проводится сравнительный анализ точностных параметров волоконно-оптического гироскопа (ВОГ) с кориолисовым вибрационным гироскопом (КВГ) с металлическим резонатором. Производители анализируемых гироскопов - Россия (ВОГ) и Украина (КВГ). Приводятся методики измерения и расчет температурной нестабильности и нелинейности масштабных коэффициентов обоих гироскопов и проводиться их сравнение. Рассчитьваются также компоненты смещения нуля при стабильной температуре и проводится их сравнительный анализ. В сравнительном анализе принимают участие два КВГ: КВГ25, КВГ43 и один ВОГ: ВГ951Д

Ключевые слова: кориолисовый вибрационный гироскоп, волоконно-оптический гироскоп, вариации Аллана, масштабный коэффициент, нелинейность, температурная нестабильность.

УДК: 004.94

М.В. Чорний, І.Б. Дуфанець

Академія сухопутних військ імені гетьмана Петра Сагайдачного, Львів

\section{МОДЕЛЮВАННЯ ТРАНСПОРТНОЇ ОБСТАНОВКИ НА ПЕРЕХРЕСТІ ДЛЯ ÏÏ ІМІТАЦІЇ НА ТРЕНАЖЕРІ}

Розглянуто методику формування імітаційної моделі регульованого перехрестя на основі його статистичного дослідження для відтворення режимів регулювання руху транспортного потоку на перехрестях в програмах візуалізації автомобільного тренажера. Дана методика дає можливість визначити оптимальну кількість транспортних засобів в потоичі на перехресті, розподіл їх по смугах руху з метою забезпечення адекватності його проїзду.

Ключові слова: імітаційне моделювання, автомобільний тренажер.

\section{Вступ}

Постановка проблеми. В останній час все більше уваги приділяється питанню впровадження у систему навчання водіїв сучасних комп'ютерних автомобільних тренажерів. Практичне застосування тренажерів дозволяє істотно скоротити витрати на підготовку водія, що привело до широкого їх впровадження у Збройних Силах.

Для більш ефективного застосування тренажерів у навчанні необхідно забезпечити адекватність відтворення транспортної обстановки на віртуальній трасі реальному маршруту, який визначений для навчання. Особливо це стосується проїзду перехресть як найбільш складних елементів маршруту.

Забезпечення адекватності комп'ютерних автомобільних тренажерів припускає вирішення ряду організаційних і технічних задач, у тому числі:

організацію оперативного збору й обробки інформації про дорожню обстановку на маршруті, який визначений для навчання водінню, що дозволяє визначити фактичні закони розподілу завантаженості перехресть на маршруті;

розробку імітаційної моделі наявних перехресть на маршруті руху; 